\title{
The Relationship between Shift Work and Occupational Fatigue on Nurses Working on the Pediatrics and Internal Wards of Muhammadiyah Palembang Hospital
}

\author{
Ardi Artanto ${ }^{1}$, Liza Chairani ${ }^{2}$, Melisa Nopa Belia ${ }^{3}$, Ahmad Ghiffari ${ }^{4}$ \\ 1,2,4Faculty of Medicine, Universitas Muhammadiyah Palembang, Indonesia \\ ${ }^{3}$ Medical Study Program at Universitas Muhammadiyah Palembang, Indonesia \\ Email:ahmad_ghiffari@um-palembang.ac.id
}

\begin{abstract}
:
Shift work is a method of allocating work time to different workgroups. Fatigue is defined as an abnormal sensation of tiredness, sluggishness, or a lack of desire to engage in activities, which results in stress, depression, or other negative emotions. In order to satisfy patients within 24 hours, hospitals must organize nurses by shift. The goal of this study at Muhammadiyah Palembang Hospital was to see if there was a link between shift work and fatigue in pediatric and internal ward nurses. This cross-sectional and analytic study entailed 26 respondents from the total sampling method used. In this study, those who worked shifts included those who worked in the morning (12 respondents $(46.2 \%)$, evening (8 respondents $(30.8 \%)$ ), and night (6 respondents $(23.1 \%)$. Fatigue has been linked to $38 \%$ of RSMP's overworked pediatric ward nurses and interna, with a p-value of 0.029. The hospital should provide rest periods for nurses, especially those who work the last shift because they must adapt during the night.
\end{abstract}

Keywords:

night shift; nurses; tiredness; burnout

\section{Introduction}

Shift work is a regular feature in industry, hospitals and many other sectors and will be inevitable as growth and development in the industry will continue (Selvi, Jayabharathi, Minisha, Swratha, \& Priya, 2021). Shift work has some advantages and disadvantages for employers, employees and their families. The advantage for entrepreneurs is the optimal use of energy, facilities, and other resources through an extension of the operating time of capital. Benefits for employees include increased income, more free time for daily activities, and saving time by avoiding rush hour traffic. Shift work is associated with short- and long-term harm to physical and psychophysiological health. Short-term effects include fatigue and trouble sleeping (Saleh et al., 2018).

Fatigue is applied to various conditions and outcomes of most job tasks due to a more subtle psychophysiological process. Fatigue is an abnormal feeling of tiredness, sluggishness, loss of drive and merging into several others, which are equally difficult to define, like stress, and depression. This condition is subjective, behavioral and physiological. Poorly adapted night workers experience a potentially progressive condition of chronic fatigue, manifest into episodes of irritability, loss of drive, depression, loss of appetite, constipation and other disorders (Fratissier, Gauberti, Morello, \& Clin, 2021). In contrast to other agencies or institutions, nurses in hospitals must serve until the patient is discharged or treated as an outpatient. Nurses in hospitals must be managed according to work shifts to serve patients within 24 hours (Chang \& Peng, 2021). 
Shift work is familiar in the industry, hospitals, and a variety of other essential sectors today, and the impact of pitfalls will be unavoidable if the industry's current growth and development continues at its current rate (Kang, Lee, \& Jang, 2021). Palembang Muhammadiyah Hospital (RSMP) is a class $\mathrm{C}$ hospital with a high referral volume, suggesting that nurses are more prone to job fatigue. This study's specific goal is to determine the relationship between shift work and fatigue in pediatric ward nurses and diseases in the RSMP setting. Hospitals, health centers, and other institutions should minimize nurse fatigue and thus improve patient care.

\section{Review of Literatures}

\subsection{Shift Work}

Shift work is a work schedule that enables workers to shift between workgroups after a certain time. Rotational and permanent shifts are the two types of work shifts. Shifts that rotate regularly are known as rotating shifts. Employees in a rotating system are not always assigned to fixed shifts. Shift rotation may be done in two ways: slowly and quickly. Slower rotations take a month, while quicker rotations take a week. The most challenging rotational adjustment to the circadian cycle is a hard rotational shift. Workers may, however, opt to work on a permanent shift schedule. Employees who work a fixed night shift must regularly work at night and sleep during the day (Thompson, 2021).

The Minister of Manpower and Transmigration produced Decision No.Kep.102/MEN/VI/2004 on working-hour rules were divided into two systems. The first option is seven working hours each day, or 40 working hours per week, for six days. The second option is 8 hours each day, five days per week, 40 hours per week. (Menteri Tenaga Kerja dan Transmigrasi Republik Indonesia, 2004). Job shifts are assigned to each employee since certain work processes cannot be stopped. Regulations are implemented to find a balance between the company's productivity and the employees' requirements for recuperation.

The goal of a hospital work shift is to continuously treat patients. The patient's health must be checked frequently. The doctor then decides the next medical step based on the patient's medical history. Monitoring the patient's health is difficult to accomplish due to fatigue or a shortage of nurses. The working hours are split into three shifts: morning, afternoon, and night (Min et al., 2020). The shift labor arrangement enables the firm to respond to increased demand for manufactured products better. Work shifts have been shown to have both a positive and negative effect on company productivity. The inability to adapt to body rhythms may cause health issues such as sleep loss, fatigue, lack of appetite, and gastrointestinal problems. Inability to interact with family and colleagues cause stress and unhappiness (Fratissier et al., 2021).

\subsection{Fatigue}

Fatigue is the body's defense strategy for preventing further damage and allowing for recovery after resting. The brain controls fatigue. Fatigue symptoms may vary from mild to severe, causing you to be unable to work. Workers who are fatigued lose motivation, job quality, make more errors, and have a decreased willingness to work, leading to workplace accidents. Work-related tiredness is often seen as a reduction in performance efficiency and physical strength or endurance (Brzozowski, Cho, Knudsen, \& Steege, 2021). 
Fatigue and fatigue symptoms are physiological responses in the cerebral cortex, which serve as the center of awareness. The thalamic inhibitory system influences both human response time and drowsiness. The propulsion system is located in the reticular structure and may activate different physiological activities such as labor, fighting, or escape. Workplace tiredness may result in decreased motivation, poor performance, many blunders, low productivity, workplace stress, poor job quality, occupational diseases, accidents, and fatalities. Fatigue has an impact on both the body and the mind. Chronic fatigue is a state of constant exhaustion. Consequently, there is less time to run to and from work without getting fatigued or experiencing other physiological issues. Overwork creates exhaustion as well as physiological issues such as cardiovascular disease (Woerkom, 2021).

\section{Research Methods}

This study is an observational cross-sectional design with total sampling. The study was conducted from December 16th until 25th, 2020. The study included nurses from the RSMP's pediatric and internal wards. Working shifts were investigated as an independent variable and work-related fatigue as a dependent variable. For Indonesian workers, the Kuesioner Alat Ukur Perasaan Kelelahan Kerja (KAUPK2) fatigue scale is used to evaluate work weariness. KAUPK2 investigates workplace concerns. It has 17 questions that have been tested and validated. Inactivity, motivation, and physical symptoms are all assigned up to 7 points. Each question has three possible answers: often, seldom, and never, each having a point value of 2,1 , or 0 .

Data for this study were collected directly during the study through respondent interviews using a questionnaire completed with informed consent. These are presented in a narrative format with frequency distribution tables for univariate analysis and KolmogorovSmirnov format for bivariate analysis (Masturoh \& T, 2018). The study obtained ethical clearance No. 58/EC/KBHKI/FK-UMP/XI/2020 from the Bioethical, Humaniora, and Islamic Medicine Committee of FK UM Palembang.

\section{Discussion}

\subsection{Socio-Demographic Data of Respondent}

The age, gender, and employment history of respondents from 26 research samples were observed and analyzed. Late adolescence (17-25 years), early adulthood (26-35 years), and late adulthood (36-50 years) (Michel, Leonardi, Martin, \& Prina, 2021). Table 1 shows that respondents aged 26-35, or early adult, are the most numerous, with 12 respondents (46.1\%). The majority of respondents $(88.5 \%)$ and the most prolonged working period (ten years) were female. Table 2 shows that those who worked the morning shift accounted were twelve $(46.2 \%)$, the afternoon shift eight $(30.8 \%)$, and the night shift reported were six persons $(23.1 \%)$. Work-related fatigue is shown in Table 3, with 16 respondents $(61.5 \%)$ reporting no fatigue and ten respondents reporting fatigue $(38.5 \%)$.

A survey of 26 nurses working in the pediatric and internal medicine wards at Muhammadiyah Hospital Palembang discovered that $12(46 \%)$ worked the morning shift. The majority of respondents (16 out of $61.5 \%$ ) reported no work-related fatigue. The relationship between shift work and fatigue in pediatric ward nurses and internal medicine at Muhammadiyah Palembang Hospital was investigated in this study ( $\mathrm{p}$-value 0.029). A work schedule allows employees to switch between workgroups after a set period, using the entire period allotted for their duties. "Continuous work shift" refers to working at the exact location and time every day (rotational work shift). Unlike a typical working day, shift work is 
completed regularly at a set time, whereas work shifts can be completed multiple times to meet a 24-hour schedule. Another reason for shift work is community demand. Inpatient hospitals must employ shift work patterns in order to offer adequate care to all of their patients. Working hours have already been defined, and companies and healthcare institutions must respect them. Aside from being open 24 hours a day, hospitals rely on nurses to provide quality patient care.

Table 1. Characteristics of Respondents $(n=26)$

\begin{tabular}{lll}
\hline Characteristics & $\mathrm{N}$ & Percentage $(\%)$ \\
\hline Age group (years) & 3 & \\
Late teens (17-25) & 12 & 11.5 \\
Early adulthood (26-35) & 11 & 46.1 \\
Late adulthood (36-45) & & 42.4 \\
Gender & 3 & \\
Man & 23 & 11.5 \\
Woman & & 88.5 \\
Length of work & 3 & \\
1 year & 3 & 11.5 \\
2 years & 1 & 11.5 \\
5 years & 1 & 3.8 \\
7 years & 2 & 3.8 \\
8 years & 2 & 7.7 \\
9 years & 7 & 7.7 \\
10 years & 3 & 26.9 \\
12 years & 1 & 11.5 \\
13 years & 1 & 3.8 \\
14 years & 1 & 3.8 \\
15 years & 1 & 3.8 \\
20 years & & 3.8 \\
\hline
\end{tabular}

Table 2. Shift Working Frequency Distribution $(\mathrm{n}=26)$

\begin{tabular}{ccc}
\hline $\begin{array}{c}\text { Shift Work Frequency } \\
\text { Distribution }\end{array}$ & Frequency & $\begin{array}{c}\text { Percentage } \\
\mathbf{( \% )}\end{array}$ \\
\hline Morning & 12 & 46.2 \\
Afternoon & 8 & 30.8 \\
Evening & 6 & 23.1 \\
Total & 26 & 100 \\
\hline
\end{tabular}

Table 3. Distribution of Work Fatigue Frequency $(n=26)$

\begin{tabular}{ccc}
\hline $\begin{array}{c}\text { Work Fatigue } \\
\text { Frequency Distribution }\end{array}$ & Frequency & Percentage (\%) \\
\hline Fatigue & 10 & 38.5 \\
Not Fatigue & 16 & 61.5 \\
\hline Total & 26 & 100 \\
\hline
\end{tabular}




\subsection{Relationship of Works Shifts and Fatigue in Nurses}

A bivariate analysis of pediatric ward nurses and internal medicine residents was performed to see if shift work and fatigue were related. The chi-square test was used for bivariate analysis with a 95\% level of significance. The Kolmogorov-Smirnov test is used instead because some cells in the $2 \times 3$ tables have expected values less than five. Table 4 shows that of the 12 respondents who worked the morning shift, $11(91.6 \%)$ did not experience fatigue, one $(8.4 \%)$ did, and five $(62.5 \%)$ did, of the eight respondents who worked the afternoon shift. One statistical study discovered no statistically significant link between shift work and fatigue $(\mathrm{p}=0.683>0.05)$ (Ginting \& Malinti, 2021). Researchers should include controllable characteristics such as age, gender, and marital status, as well as other variables, when assessing fatigue levels among departments.

Nurses' workplace fatigue differs according to whether they work morning, afternoon, or night shifts. The night shift is 10 hours. The load on each ward varies according to patient conditions. Since the nurse is constantly on call, she must resist fatigue (Ahmad \& Amanatun, 2015). The brain manages cellular fatigue. In general, fatigue symptoms range from mild to incapacitating. Fatigue workers have lower motivation, lower quality work, more errors, less drive to work, and less ability to prevent workplace accidents. Due to the varying conditions of the patients, the workload varies between wards. Even though the number of activities is lower than on the morning shift, nurses must be exhausted due to being on call. After 1 a.m., nurses can only sleep alternately to ensure patient safety (Aini, 2018). Catabolism or energy destruction and readiness to act during the day, for example, and anabolism or regeneration and readiness to act during the night.

Table 4. Relationship between Shift Work and Work Fatigue $(\mathrm{n}=26)$

\begin{tabular}{cccccccc}
\hline \multirow{2}{*}{$\begin{array}{l}\text { Work } \\
\text { Shift }\end{array}$} & \multicolumn{7}{c}{ Work Fatigue } \\
\cline { 2 - 8 } & \multicolumn{2}{c}{ Not Fatigue } & \multicolumn{7}{c}{ Fatigue } & Amount & Kolmogorov-Smirnov \\
\cline { 2 - 8 } & $\mathrm{N}$ & $\%$ & $\mathrm{~N}$ & $\%$ & $\mathrm{~N}$ & $\%$ & \\
\hline Morning & 11 & 91.6 & 1 & 8.4 & 12 & 46.2 & \multirow{2}{*}{0.029} \\
Afternoon & 3 & 37.5 & 5 & 62.5 & 8 & 30.8 & \\
Evening & 2 & 33.3 & 4 & 66.7 & 6 & 23.1 & \\
\hline Total & 16 & 61.5 & 10 & 38.5 & 26 & 100 & \\
\hline
\end{tabular}

Lack of sleep combined with working at a physiologically low point in the body can cause excessive fatigue and sleepiness, making quality work difficult and increasing the risk of an accident. Unusual working conditions or fatigue reduce an operator's work capacity, increasing the likelihood of a mistake (Susetyo, Oesman, \& Sudharman, 2012). The human body was designed to follow the natural world's cycles. Even when the body is resting in the afternoon or at night, all parts are active. The body has an inbuilt timekeeper called a body clock or circadian rhythm. This biological clock controls work, sleep, and food digestion. Afternoon activity increases heart rate and blood pressure. During the night, all bodily functions slow down, resulting in significant fatigue.

The natural conditions of day and night support this conclusion. It is difficult to change one's physical condition. As a result, when the body is required to work at night, adjustments and arrangements for the proper work schedule must be made (Jhonni Wahyudi, Gerry Silaban, \& Destanul Aulia, 2020). Moreover, good knowledge of occupational health and safety regarding maintaining the body rhythm while working can play a role. Good knowledge of occupational health and safety is related to unsafe acts (Jhonni Wahyudi et al., 2020). Occupational fatigue among nurses could be unsafe conditions that will arise into unsafe acts if the employees who work in the hospital ward were fatigued. This kind of 
knowledge should be socialized continuously by the employer or, in this case, the hospital. Even if the nurse who got the information said the socialization was ineffective, this process must be brought because this is an important point (Yulisnawati, Zulfendri, \& Siti Saidah Nasution, 2020). The employee perception toward occupational health and safety culture was expected to make work safer, healthier, and more productive (Melda Sari Tarigan, Gerry Silaba, \& Zulfendri, 2020).

\section{Conclusion}

At Muhammadiyah Hospital Palembang, there were $46 \%$ respondents who worked the morning shift, 30\% who worked the evening shift, and $24 \%$ who worked the night shift. $61.5 \%$ participants were not fatigued, while $38.5 \%$ were. Fatigue has been linked to RSMP's overworked pediatric ward nurses and interna, with a p-value of 0.029. Hospitals should provide rest periods for nurses, especially those who work late shift, because they must adapt during the night.

\section{References}

Ahmad, S., \& Amanatun, A. (2015). Beban kerja dengan kelelahan kerja pada pekerja industri keripik melinjo di Desa Benda Indramayu. Jurnal Kesehatan Masyarakat, 1(3), 25-30.

Aini, N. (2018). Hubungan shift kerja dengan kelelahan kerja pada perawat di instalasi rawat inap di Rumah Sakit Herna Medan tahun 2018. Jurnal Jumantik, 4(1), 45-56.

Brzozowski, S. L., Cho, H., Knudsen, N. A., \& Steege, L. M. (2021). Predicting nurse fatigue from measures of work demands. Applied Ergonomics, 92(September 2020), 103337. https://doi.org/10.1016/j.apergo.2020.103337

Chang, W.-P., \& Peng, Y.-X. (2021). Differences between fixed day shift nurses and rotating and irregular shift nurses in work- related musculoskeletal disorders: A literature review and meta- -analysis. Journal of Occupational Health, 63, e12208. https://doi.org/10.1002/1348-9585.12208

Fratissier, A., Gauberti, P., Morello, R., \& Clin, B. (2021). Impact of 12-hr shifts in general hospitals: Study conducted in two intensive care units. Nursing Open, 8(June 2020), 656-663. https://doi.org/10.1002/nop2.670

Ginting, N. B., \& Malinti, E. (2021). Hubungan shift kerja dengan kelelahan kerja pada perawat di bangsal rawat inap rumah sakit Advent Bandar Lampung. Nutrix, 5(1), 34 38.

Jhonni Wahyudi, Gerry Silaban, \& Destanul Aulia. (2020). The Relationship between Motivation Factors and Unsafe Action on Passenger Ship Crews in Tanjung Pinang. Britain International of Exact Sciences (BIoEx) Journal, 2(1), 390-404. https://doi.org/10.33258/bioex.v2i1.174

Kang, H., Lee, M., \& Jang, S. J. (2021). The impact of social jetlag on sleep quality among nurses: A cross-sectional survey. International Journal of Environment Research and Public Health, 18(47), 1-11.

Masturoh, I., \& T, N. A. (2018). Metodologi Penelitian Kesehatan.

Melda Sari Tarigan, Gerry Silaba, \& Zulfendri. (2020). The Implementation Effectiveness of the K3RS Program with Achievement of Compliance on Hospital Accreditation Standards at Dr. R. M. Djoelham Hospital in Binjai of 2019. Britain International of Exact Sciences (BIoEx) Journal, 2(1), 251-261. https://doi.org/10.33258/bioex.v2i1.133 
Menteri Tenaga Kerja dan Transmigrasi Republik Indonesia. (2004). Keputusan Menteri tenaga kerja dan transmigrasi republik Indonesia, Tentang waktu kerja lembur dan upah kerja lembur.

Michel, J.-P., Leonardi, M., Martin, M., \& Prina, M. (2021). WHO's report for the decade of healthy ageing 2021-30 sets the stage for globally comparable data on healthy ageing. https://doi.org/10.1016/S2666-7568(21)00002-7

Min, A., Kim, Y. M., Yoon, Y. S., Hong, H. C., Kang, M., \& Scott, L. D. (2020). Effects of work environments and occupational fatigue on care left undone in rotating shift nurses. Journal of Nursing Scholarship, 1-11. https://doi.org/10.1111/jnu.12604

Saleh, M. A., Elhady, H. M., Waly, M. H., Elbakry, S. T., Baioumy, H. E., \& Zaki, M. S. (2018). Shiftwork-related problems among nurses working in Benha University Hospital, Egypt. Menoufia Medical Journal VO - 31, 31, 619-628. https://doi.org/10.4103/1110-2098.239740

Selvi, K. S., Jayabharathi, B., Minisha, S., Swratha, K., \& Priya, M. V. (2021). Assessment of impact of shift work on health among staff nurses at SRM General Hospital, Kattankulathur. International Journal of Nursing Education, 13(1), 80-84.

Susetyo, J., Oesman, T. I., \& Sudharman, S. T. (2012). Pengaruh shift kerja terhadap kelelahan karyawan dengan metode Bourdon Wiersma dan 30 items of Rating Scale. Jurnal Teknologi.

Thompson, B. J. (2021). Fatigue and the female nurse: A narrative review of the current state of research and future directions. Women's Health Report, 2, 53-61. https://doi.org/10.1089/whr.2020.0107

Woerkom, M. Van. (2021). A quasi-experimental study into the effects of naps and therapy glasses on fatigue and well-being. Journal of Nursing Management, 29(September 2020), 562-571. https://doi.org/10.1111/jonm.13172

Yulisnawati, Zulfendri, \& Siti Saidah Nasution. (2020). Nurse's Perception of Patient Safety Culture in an Effort to Improve Service Quality in the Operating Room of Riau Province Hospital. Britain International of Exact Sciences (BIoEx) Journal, 2(1), 8494. https://doi.org/10.33258/bioex.v2i1.100 